\title{
PENGARUH PEMBERIAN JAHE MERAH (Zingiber officinale var rubrum) TERHADAP KADAR KOLESTEROL LDL WANITA DISLIPIDEMIA
}

\author{
Hanum Putri Hapsari, Hesti Murwani Rahayuningsih*) \\ Program Studi Ilmu Gizi Fakultas Kedokteran Universitas Diponegoro \\ J1.Dr.Sutomo No.18, Semarang, Telp (024) 8453708, Email : gizifk@ undip.ac.id
}

\begin{abstract}
Background: Elevated levels of LDL cholesterol increase the risk of cardiovascular disease. Red ginger, widely consumed as spice, has also been used as traditional herbal medicine. Red gingerwas analternative source of flavonoidin food which was able to lowered LDL cholesterol level. The aim of this study was to analyze the effects of red ginger administration towards LDL cholesterol level in dyslipidemiawomen.

Methods: A true experimentalwith pre-post testcontrol group design was conducted to 34 dyslipidemia women with LDL cholesterol level more than $100 \mathrm{mg} / \mathrm{dl}$ to $159 \mathrm{mg} / \mathrm{dl}$ which grouped using simple random sampling system into 1 control group and 1 treatment group. The subject was given red ginger drink at dosage 3,2 ml/kg body weight for 21 days. LDL cholesterol level was determined using direct homogenous enzymatic methodafter an overnight fast 10 hours. Shapiro-Wilk was used to analyze normality of the data. All datas collected were analyzed using dependent $t$ test,independent t-test, Mann-Whitney, Pearson test, and Spearman test at $95 \%$ confidence level.

Result: Red ginger administration was able to lowered LDL cholesterol level at treatment group as much as $12,75 \%$. Conclusion: Red ginger administration at 3,2 ml/kg body weight dossages for 21days is able to show significant lowering effect to LDL cholesterol level in dyslipidemia women.
\end{abstract}

Key words: red ginger; LDL cholesterol; dyslipidemia

\section{ABSTRAK}

LatarBelakang: Peningkatan kadar kolesterol LDL meningkatkan risiko terjadinya penyakit kardiovaskuler. Jahe merah, yang banyak dikonsumsi sebagai bumbu, sudah digunakan sebagai pengobatan herbal tradisional. Jahe merah merupakan bahan makanan alternative yang mengandung flavonoid yang dapat menurunkan kadar kolesterol LDL. Penelitian ini bertujuan untuk menganalisis pengaruh pemberian jahe merah terhadap kadar kolesterol LDL pada wanita dislipidemia.

Metoda: Penelitian true experimental dengan pre-post test control group diterapkan pada 34 wanita dislipidemia dengan kadar kolesterol LDL lebih dari $100 \mathrm{mg} / \mathrm{dl}$ sampai $159 \mathrm{mg} / \mathrm{dl}$ yang dikelompokkan menggunakan sistem acak sederhana menjadi 1 kelompok perlakuan dan 1 kelompok kontrol. Subjek diberikan minuman jahe merah dengan dosis 3,2 ml/kg berat badan selama 21 hari. Kadar kolesterol LDL ditentukan melalui metode langsung (direct homogenous enzymatic method) setelah subjek berpuasa selama 10 jam. Uji normalitas menggunakan Shapiro-Wilk. Data dianalisis dengan dependent t-test, independent t-test, Mann-Whitney, uji Pearson, dan uji Spearman pada tingkat kepercayaan $95 \%$.

Hasil: Pemberian jahe merah dapat menurunkan kadar kolesterol LDL pada kelompok perlakuan sebesar 12,75\%. Kesimpulan: Pemberian jahe merah dengan dosis 3,2 ml/kg berat badan selama 21 hari dapat menurunkan kadar kolesterol LDL secara signifikan padawanitadislipidemia.

Kata kunci :jahemerah; kolesterolLDL; dislipidemia

\section{PENDAHULUAN}

Penyakit kardiovaskuler merupakan penyebab kematian utama di dunia. Menurut badan kesehatan dunia (WHO) pada tahun 2008, setidaknya 17,3 juta orang meninggal akibat penyakit kardiovaskuler yang mewakili $30 \%$ dari seluruh kematian global. Angka ini diperkirakan akan terus meningkat mencapai 23,3 juta kematian di dunia pada tahun 2030. ${ }^{1}$ Pada tahun 2011 Profil kesehatan Provinsi Jawa Tengah melaporkan bahwa terdapat $62,43 \%$ (880.193) penyakit kardiovaskuler dari total 1.409.857 kasus penyakit tidak menular. ${ }^{2}$ Data Dinas Kesehatan Kota Semarang tahun 2012 terdapat 8.462 kasus penyakit kardiovaskuler dengan rentang umur 15-64 tahun. Pada tahun 2012 terdapat 1344 kasus kematian yang diakibatkan karena penyakit kardiovaskuler. Jumlahnya menurun pada tahun 2013 menjadi 960 kasus namun masih menjadi penyebab kematian tertinggi di Semarang. ${ }^{3,4}$

Dislipidemia merupakan salah satu faktor risiko penyakit kardiovaskuler yang ditandai dengan tidak normalnya jumlah lemak dalam darah. Meningkatnya kadar koleserol dan lipoprotein merupakan indikator lipid penyebab utama dislipidemia. ${ }^{5}$ Kolesterol adalah komponen semua membran sel di dalam tubuh. Kolesterol LDL berfungsi mengangkut kolesterol ke sel perifer di

\footnotetext{
${ }^{*}$ Penulis Penanggungjawab
} 
seluruh tubuh. Penurunan kolesterol LDL adalah faktor risiko yang dapat dimodifikasi pada wanita dislipidemia. ${ }^{6}$

Profil lipid serum dapat diperbaiki dengan modifikasi diet. Diet memberikan efek yang lebih aman sehingga sangat dianjurkan. Selain membatasi konsumsi makanan yang berasal dari lemak sumber hewani juga dianjurkan untuk konsumsi jenis bahan makanan yang memiliki kandungan antioksidan.Zingiber officinalevar rubrumatau jahe merah adalah rempah-rempah yang memiliki kandungan antioksidan. Indonesia adalah salah satu negara penghasil jahe yang sudah mengekspor jahe ke Jepang, Amerika, Saudi Arabia, dan Malaysia. ${ }^{7}$ Jahe sudah lama digunakan sebagai obat tradisional di Indonesia. Kegunaan jahe antara lain sebagai kemoprotektif, hipolipidemik, anti inflamasi, anti viral, anti mual dananti muntah,migrain, dan anti ulserogenik. ${ }^{8,9}$

Jahe mengandung senyawa volatile dan non volatile. Senyawa volatile terdiri dari berbagai senyawa terpenoid. Senyawa non-volatile terdiri dari senyawa-senyawa flavonoid dan polifenol ([6]gingerol dan turunanannya) yang mempunyai aktivitas antioksidan tinggi untuk mencegah adanya radikal bebas dalam tubuh. ${ }^{10,}{ }^{11}$ Jahe dapat meningkatkan aktivitas enzim 7ळ-hydroxylase yang berperan dalam biosistesis asam empedu dan merangsang perubahan kolesterol menjadi asam empedu yang menyebabkan eksresi kolesterol dalam tubuh. ${ }^{12}$ Jahe juga meningkatkan kapasitas antioksidan plasma total dan menurunkan peroksidasi lipid. ${ }^{13}$

Penelitian sebelumnya mengenai pemberian serbuk jahe dengan dosis 5,7 $\mathrm{mg}$ /ekor/hari selama 14 hari dapat menurunkan efek radikal bebas malondialdehida (MDA) pada tikus putih yang diinduksi $\mathrm{CCl}_{4}$ dalam plasma darah. ${ }^{14}$ Pemberian jus jahe $4 \mathrm{ml}$ selama 21 hari pada tikus dapat menurunkan kolesterol LDL namun tidak signifikan. ${ }^{15}$ Penelitian lainmenggunakan ekstrak jahe $300 \mathrm{mg} / 100 \mathrm{ml} / \mathrm{kg}$ berat badan (BB) selama 49 hari pada tikusRattus novergicus yang telah diinduksi vanaspati didapatkan hasil penurunan kolesterol LDL yang lebih rendah jika dibandingkan dengan kelompok yang tidak diberi ekstrak jahe. ${ }^{16}$ Selain itu penelitian menggunakan jus jahe $4 \mathrm{ml}$ per $\mathrm{kg}$ berat badan selama 10 hari terhadap tikus yang diinduksi aloksan signifikan dapat menurunkan kadar kolesterol LDL. ${ }^{17}$

Jahe merah diolah menjadi minuman yang berbahan dasar jahe merah dengan penambahan air dan pemanis. Jahe merah dalam bentuk minuman lebih mudah dibuat dan dikonsumsi dibandingkan dengan jahe yang diekstrak atau dibuat menjadi serbuk. Pengolahan jahe merah menjadi minuman dapat mengoptimalkan pemanfaatannya. Selain itu minuman dari jahe segar lebih banyak mengandung senyawa aktif seperti zingeberen dan minyak atsiri dibandingkan dengan jahe kering. Kandungan minyak atsiri yang lebih tinggi berkorelasi dengan tingginya kandungan antioksidannya. ${ }^{18}$ Minuman jahe merah memiliki kandungan total fenol 387.93 ppm dan aktivitas antioksidan sebesar $62.19 \% .{ }^{19}$

Penelitian menggunakan jahe merah pada manusia belum pernah dilakukan sebelumnya, karena itu peneliti ingin melakukan penelitian pengaruh pemberian jahe merah terhadap kadar kolesterol LDL pada wanita dengan dislipidemia. Dosis yang akan digunakan adalah $3,2 \mathrm{ml} / \mathrm{kg}$ BB per hari. Pemberian dosis ini belum pernah dilakukan pada manusia dan berdasarkan hasil konversi dosis dari penelitian terdahulu yang telah membuktikan pemberian jahe merah sebanyak $4 \mathrm{ml} / \mathrm{kg}$ BB pada tikus dapat menurunkan kolesterol LDL. ${ }^{17} \mathrm{Hal}$ inilah yang mendasari dilakukannya penelitian ini. Pemilihan subjek penelitian di lingkungan kantor Sekertaris Daerah (SETDA) Provinsi Jawa Tengah, kantor Dinas Pengelolaan Keuangan Dan Aset Daerah (DPKAD) Kota Semarang, dan Badan Perencanaan Pembangunan Daerah (BAPPEDA) Kota Semarang dianggap dapat mewakili populasi dengan aktivitas fisik yang sama.

\section{METODE}

Penelitian ini menggunakan desain true eksperimental dengan rancangan pre-post control group design. ${ }^{20}$ Variabel terikat (dependent)dalam penelitan ini adalah kadarkolesterol LDL, sedangkan variabel bebas (independent)adalah pemberian jahe merah. Variabel perancu(confounding) adalah asupan zat gizi yang terdiri dari asupan energi, asupan protein, asupan karbohidrat, asupan lemak, asupan serat, dan asupan kolesterol selama penelitian selain dari intervensi yang diberikan.

Subjek penelitian adalah karyawati kantor SETDA Provinsi Jawa Tengah, kantor DPKADKota Semarang, dan BAPPEDAKota Semarang.Kriteria inklusi memiliki kadar kolesterol LDL lebih dari $100 \mathrm{mg} / \mathrm{dl}$ hingga $159 \mathrm{mg} / \mathrm{dl}$, indeks massa tubuh (IMT) lebih dari $18,5 \mathrm{~kg} / \mathrm{m}^{2}$, belum mengalami menopause, tidak sedang dalam keadaan hamil dan menyusui, bersedia menjadi subjek penelitian, tidak sedang mengonsumsi obatanti hiperlipidemia, dan tidak dalam perawatan dokter terkait penyakit jantung dan pembuluh darah, diabetes melitus, hipertensi, gagal ginjal, tidak merokok dan tidak mengonsumsi alkohol. 
Perhitungan subjek penelitan menggunakan rumus uji hipotesis terhadap rerata dua populasi independen dan dibutuhkan sebanyak 30subjek. Penentuan subjek penelitian menggunakan metode consecutive sampling. Sebanyak 53 orang bersedia diambil darahnya untuk proses skrining awal. Kadar kolesterol LDL dianalisis dengan pemeriksaan laboratorium menggunakan metode langsung (direct homogenous enzymatic method).Darah diambil dari pembuluh venaoleh petugas laboratorium setelah subjek berpuasa selama \pm 10 jam. Dari proses skrining awal diperoleh sebanyak 36 orang yang memenuhi kriteria inklusi untuk menjadi subjekpenelitian. Subjek dibagi menjadi 2 kelompok dengan metodesimple random sampling, yang terdiri atas satu kelompok kontrol dan satu kelompok perlakuan, masing-masing kelompok terdiri atas 18 subjek.
Setelah subjek terpilih dan dibagi menjadi dua kelompok maka kelompok perlakuan diberikan minumanjahe merahdengan dosis $3.2 \mathrm{ml} / \mathrm{kg}$ BB per hari dan kelompok kontrol diberikan placebo yaitu sirup rendah kalori $25 \mathrm{ml}$ yang telah ditambahkan air sebanyak $200 \mathrm{ml}$. Pemberian minuman jahe merahdan placebo dilakukan selama 21 hari. Pembuatan minuman jahe merah menggunakan metode pada penelitian Mayani, dkk. ${ }^{(19)}$ Asupan sehari-hari baik untuk kelompok kontrol maupun perlakuan tidak dikontrol dan dibiarkan sebagaimana biasanya. Sementara kepatuhan konsumsi jahe merah dan placebo dikontrol dengan menggunakan formulir daya terima.Terdapat 2subjek yang drop outpada kelompok kontrol dalam penelitian ini karena mengonsumsi obat antihiperlipidemia.

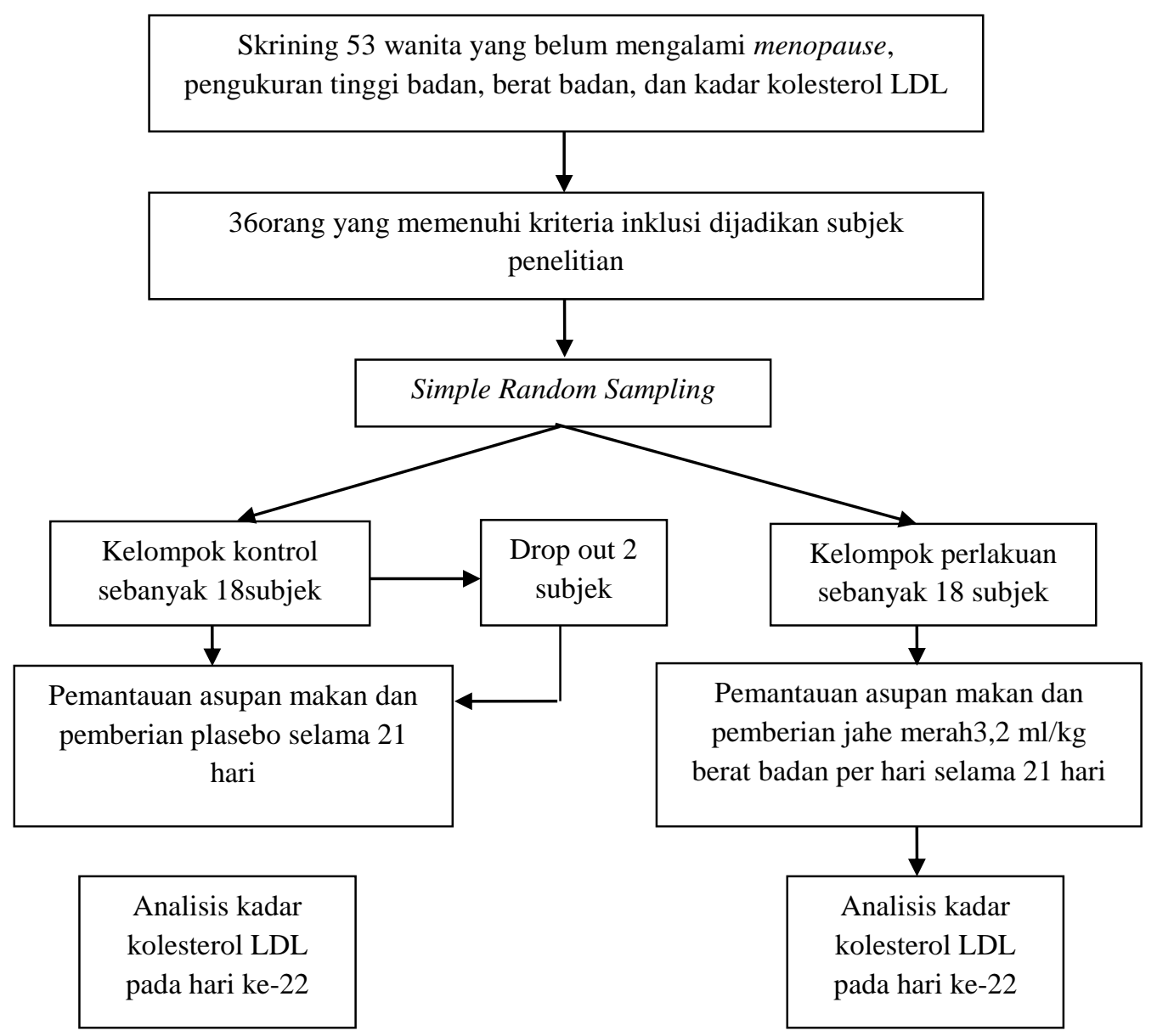

Gambar 1. Bagan alur kerja penelitian

Klasifikasi IMT menggunakan kategori WHO menurut kriteria Asia Pasifik. ${ }^{21}$ Pencatatan asupan zat gizi dilakukan menggunakan food recordselama penelitian sebanyak 6 kali yang dilakukan pada 3 hari kerja dan 3hari libur. ${ }^{22}$ Data asupan zat gizi pada food recorddalam satuan ukuran rumah tangga (URT) dikonversi ke dalam satuan gram kemudian dianalisis menggunakan program nutrisoft.Kebutuhan individu diperoleh dengan mengkonversikan angka kecukupan gizi (AKG) untuk individu dengan cara membandingkan berat badan aktual dengan berat badan rujukan 
untuk usia 30-50 tahun pada tabel AKG 2013, kemudian dikalikan $100 \%$ maka didapatkan persen tingkat kecukupan asupan zat gizi. Tingkat asupan zat gizi dibagi menjadi 3 kategori, yaitu baik (>100\% AKG), sedang (81-99\% AKG), dan kurang $\left(<80 \%\right.$ AKG). ${ }^{23}$ statistik.Analisis univariat dilakukan untuk mendeskripsikan data karakteristiksubjek.Data tersebut diuji normalitas menggunakanshapirowilk.Data usia, asupan serat, dan rerata perubahan kadar kolesterol LDL yang berdistribusi tidak normal dilakukan uji non parametrik. Perbedaan
Semua data diolah menggunakan program

kadar kolesterol LDLsebelum dan sesudah perlakuan diuji dengan dependent t-test. Perbedaan pengaruh perlakuan kedua kelompok dianalisis denganindependent t-testdan ujiMann-Whitney. Analisis bivariat dilakukan untuk melihat hubunganasupan zat gizi pada kelompok kontrol dan perlakuanterhadapreratakadarkolesterol LDL. Data diuji dengan uji Pearson dan uji Spearman.Pengujian dilakukan dengan tingkat signifikansi $(\alpha) 0,05$ dan tingkat kepercayaan 95\%.

\section{HASIL}

\section{Karakterisktik subjek}

Tabel 1. Karakteristiksubjek sebelum penelitian

\begin{tabular}{|c|c|c|c|c|c|}
\hline \multirow[b]{2}{*}{ Variabel } & \multicolumn{2}{|c|}{ Perlakuan $(n=18)$} & \multicolumn{2}{|c|}{ Kontrol $(n=16)$} & \multirow[b]{2}{*}{$\mathbf{p}$} \\
\hline & Mean \pm SD & $\begin{array}{c}\text { Median (min- } \\
\text { max) }\end{array}$ & Mean \pm SD & $\begin{array}{c}\text { Median } \\
\text { (min-max) }\end{array}$ & \\
\hline Usia (tahun) & & $45,50(34-50)$ & & $45.50(33-50)$ & $0,475^{b}$ \\
\hline IMT $\left(\mathrm{kg} / \mathbf{m}^{2}\right)$ & $25,96 \pm 4,48$ & & $26,12 \pm 5,76$ & & $0,935^{\mathrm{a}}$ \\
\hline Kadar Kolesterol LDL (mg/dl) & $127,82 \pm 16,54$ & & $\begin{array}{c}128,18 \pm 12,0 \\
0 \\
\end{array}$ & & $0,935^{\mathrm{a}}$ \\
\hline
\end{tabular}

Karakteristik subjek meliputi gambaran kelompok usia, IMT, dan kadar kolesterol LDL subjek sebelum penelitian. Tabel 1 menunjukkan hasil uji beda bahwa tidak terdapat perbedaan usia, IMT, dan kadar kolesterol LDL antara kelompok perlakuan dan kontrol ( $p>0,05)$.

Tabel 2. Gambaran usia dan IMTsubjek

\begin{tabular}{lcccc}
\hline \multirow{2}{*}{ Variabel } & \multicolumn{2}{c}{ Perlakuan $(\mathbf{n = 1 8})$} & \multicolumn{2}{c}{ Kontrol $(\mathbf{n = 1 6})$} \\
\cline { 2 - 5 } & $\mathbf{N}$ & $\mathbf{\%}$ & $\mathbf{n}$ & $\mathbf{\%}$ \\
\hline Usia & 2 & 5,9 & 1 & 2,9 \\
$30-35$ & 1 & 2,9 & 2 & 5,9 \\
$36-40$ & 6 & 17,6 & 5 & 14,7 \\
$41-45$ & 9 & 26,5 & 8 & 23,5 \\
$46-50$ & & & & \\
\hline IMT $\left(\mathrm{kg} / \mathrm{m}^{2}\right)$ & 4 & 11,8 & 4 & 11,8 \\
Normal $\left(18,5-22,9 \mathrm{~kg} / \mathrm{m}^{2}\right)$ & 4 & 11,8 & 5 & 14,7 \\
Overweight $\left(23,0-24,9 \mathrm{~kg} / \mathrm{m}^{2}\right)$ & 6 & 17,6 & 4 & 11,8 \\
Obesitas I $\left(25-29,9 \mathrm{~kg} / \mathrm{m}^{2}\right)$ & 4 & 11,8 & 3 & 8,8 \\
Obesitas II $\left(>30,0 \mathrm{~kg} / \mathrm{m}^{2}\right)$ & 4
\end{tabular}

Tabel 2 menunjukkan bahwa sebagian besar subjek memiliki IMT dengan kategori obesitas $I(17,6 \%)$ pada kelompok perlakuan dan overweight pada kelompok kontrol.

\section{Gambaran asupan zat gizisubjek}

Asupan zat gizisubjek yang didapatkan selama penelitian yaitu meliputi energi, karbohidrat, protein, lemak, serat, dan kolesterol.

Tabel 3. Asupan energi, protein, karbohidrat, lemak,serat, dan kolesterol

\begin{tabular}{lccccc}
\hline \multirow{2}{*}{ Asupan Zat Gizi } & Tingkat & \multicolumn{4}{c}{ Kelompok } \\
\cline { 3 - 6 } & Asupan Zat Gizi & \multicolumn{2}{c}{ Perlakuan (n=18) } & Kontrol (n=16) \\
\cline { 3 - 6 } & & $\mathbf{n}$ & $\mathbf{\%}$ & $\mathbf{n}$ & \% \\
\hline Energi & Kurang & 16 & 47,09 & 12 & 35,29 \\
& Sedang & 1 & 2,94 & 4 & 11,76 \\
& Baik & 1 & 2,94 & 0 & 0 \\
\hline Protein & Kurang & 13 & 38,23 & 12 & 35,29
\end{tabular}




\begin{tabular}{lccccc} 
& Sedang & 1 & 2,94 & 3 & 8,82 \\
& Baik & 4 & 11,76 & 1 & 2,94 \\
\hline Karbohidrat & Kurang & 18 & 52,94 & 13 & 38,23 \\
& Sedang & 0 & 0 & 2 & 5,88 \\
& Baik & 0 & 0 & 1 & 2,94 \\
\hline Lemak & Kurang & 4 & 11,76 & 4 & 11,76 \\
& Sedang & 7 & 20,58 & 4 & 11,76 \\
& Baik & 7 & 20,58 & 8 & 23,52 \\
\hline Serat & Kurang & 18 & 52,94 & 16 & 47,05 \\
& Sedang & 0 & 0 & 0 & 0 \\
& Baik & 0 & 0 & 0 & 0 \\
\hline Kolesterol & Baik & 7 & 20,58 & 8 & 23,52 \\
& Lebih & 11 & 32,35 & 8 & 23,52 \\
\hline
\end{tabular}

Tabel 3 menunjukkan bahwa asupan zat gizi kelompok perlakuan dan kontrol sebagian besar mengalami kekurangan pada energi, protein, karbohidrat, dan serat.Asupan lemak pada dua kelompok termasuk baik.Asupan kolesterol pada kelompok perlakuan sebagian besar berlebih namun pada kelompok kontrol sebagian besar termasuk baik.

Tabel 4. Asupan zat gizi subjek selama penelitian

\begin{tabular}{|c|c|c|c|c|c|}
\hline \multirow{2}{*}{ Asupan } & \multicolumn{2}{|c|}{ Perlakuan $(n=18)$} & \multicolumn{2}{|c|}{ Kontrol $(n=16)$} & \multirow[b]{2}{*}{$\mathbf{p}$} \\
\hline & Mean \pm SD & $\begin{array}{l}\text { Median (min- } \\
\text { max) }\end{array}$ & Mean \pm SD & $\begin{array}{c}\text { Median } \\
(\text { min-max })\end{array}$ & \\
\hline Energi & $1481,60 \pm 275,59$ & & $1503,98 \pm 341,99$ & & $0,834^{\mathrm{a}}$ \\
\hline Protein & $49,39 \pm 14,44$ & & $45,8031 \pm 9,54$ & & $0,405^{\mathrm{a}}$ \\
\hline Karbohidrat & $212,06 \pm 33,49$ & & $206,0275 \pm 58,69$ & & $0,711^{\mathrm{a}}$ \\
\hline Lemak & $48,93 \pm 24,05$ & & $57,5606 \pm 21,03$ & & $0,277^{\mathrm{a}}$ \\
\hline Serat & & $\begin{array}{c}9,76(4,70- \\
13,58) \\
\end{array}$ & & $\begin{array}{c}13,58(4,16- \\
24,77) \\
\end{array}$ & $0,836^{\mathrm{b}}$ \\
\hline Kolesterol & $242,56 \pm 130,03$ & & $180,73 \pm 109,02$ & & $0,146^{\mathrm{a}}$ \\
\hline
\end{tabular}

Tabel 4 menunjukkan bahwa tidak terdapat perbedaan rerata asupan energi, protein, karbohidrat, lemak, serat, dan kolesterol antara kelompok perlakuan dan kelompok kontrol $(\mathrm{p}>0.05)$.
Pengaruh pemberian jahe merahterhadaprerata kadar kolesterol LDL

Pengaruhpemberian merahterhadaprerata kadar kolesterol LDL dapatdilihatpadatabel 5.

Tabel 5.Pengaruhpemberianjahe merahterhadapreratakolesterol LDL sebelumdansetelahperlakuan

\begin{tabular}{|c|c|c|c|c|}
\hline \multirow{2}{*}{ Kelompok } & Kadar LDL pre (mg/dl) & Kadar LDL post (mg/dl) & $\Delta(\mathbf{m g} / \mathrm{dl})$ & \multirow{2}{*}{$\mathbf{p}$} \\
\hline & Mean \pm SD & Mean \pm SD & $\begin{array}{l}\text { Median(min- } \\
\max )\end{array}$ & \\
\hline Perlakuan & $128,18 \pm 12,00$ & $111,4722 \pm 16,53$ & $\begin{array}{c}14,00(6,70- \\
37,80)\end{array}$ & $0,000^{\mathrm{a}}$ \\
\hline Kontrol & $127,8222 \pm 16,53$ & $126,25 \pm 14,89$ & $\begin{array}{c}4,10(-22,00- \\
18,10)\end{array}$ & $0,455^{\mathrm{a}}$ \\
\hline $\mathbf{p}$ & $0,935^{\mathrm{b}}$ & $0,009^{\mathrm{b}}$ & $0,000^{\mathrm{c}}$ & \\
\hline
\end{tabular}

a Dependent $t$-test ${ }^{\mathrm{b}}$ Independent $t$-test $\quad{ }^{\mathrm{c}}$ Mann-Whitney

Pada tabel 5 dapat dilihat bahwa reratakolesterol LDL pada kelompok perlakuan terdapat perbedaan yang bermakna $(\mathrm{p}<0,05)$ antara sebelum dan sesudah pemberian jahe merah. Terdapat penurunan rerata kolesterol LDL pada kelompok kontrol tetapi secara statistik kadar kolesterol LDL sebelum dan sesudah perlakuan tidak terdapat perbedaan yang bermakna $(\mathrm{p}>0,05)$. Perbedaan rerata perubahan kadar kolesterol LDL antar kedua kelompok dianalisa menggunakan 
Mann-Whitney, didapatkan hasil bahwa terdapat perbedaan rerata perubahan kadar kolesterol LDL yang bermakna $(\mathrm{p}<0,05)$ antara kelompok kontrol dan kelompok perlakuan.
Hubungan asupan zat gizi terhadap rerata kadar kolesterol LDL

Hubungan asupan zat gizi pada kelompok kontrol dan perlakuan terhadap rerata kadar kolesterol LDL dapat dilihat pada tabel 6.

Tabel 6.Hubungan asupan zat gizi terhadap rerata kolesterol LDL pada kelompok perlakuan dan kelompok kontrol

\begin{tabular}{lcc}
\multicolumn{1}{c}{$\begin{array}{c}\text { Asupan zat } \\
\text { gizi }\end{array}$} & Perlakuan (n=18) & Kontrol $(\mathbf{n = 1 6})$ \\
\cline { 2 - 3 } & $\mathbf{p}$ & $\mathbf{p}$ \\
\hline Energi & $0,564^{\mathrm{a}}$ & $0,644^{\mathrm{a}}$ \\
Protein & $0,400^{\mathrm{a}}$ & $0,774^{\mathrm{a}}$ \\
Karbohidrat & $0,902^{\mathrm{a}}$ & $0,188^{\mathrm{a}}$ \\
Lemak & $0,743^{\mathrm{a}}$ & $0,314^{\mathrm{a}}$ \\
Serat & $0,911^{\mathrm{a}}$ & $0,444^{\mathrm{b}}$ \\
Kolesterol & $0,103^{\mathrm{a}}$ & $0,513^{\mathrm{a}}$ \\
\hline \multicolumn{2}{c}{}
\end{tabular}

${ }^{\mathrm{a}}$ uji Pearson ${ }^{\mathrm{b}}$ uji Spearman

Hubungan asupan zat gizimasing-masing kelompok dianalisa menggunakan uji Pearson dan uji Spearman, didapatkan hasil bahwa yang berhubungan kadar kolesterol LDL pada kelompok perlakuan adalah jahe merah karena tidak ada keterkaitan antara asupan zat gizi degan kadar kolesterol LDL ( $>00,05)$. Pada kelompok kontrol asupan zat gizi tidak berkorelasi dengan kadar kolesterol LDL( $p>0,05)$.

\section{PEMBAHASAN}

Peningkatan kadar kolesterol LDL merupakan faktor risiko penyakit kardiovaskuler yang dapat dimodifikasi pada wanita. Kadar kolesterol LDL cenderung mengalami peningkatan dengan bertambahnya usia karena aktivitas reseptornya yang menurun. ${ }^{6}$ Subjek dislipidemia pada penelitian ini berusia 30-50 tahun sejalan dengan penelitian di Pakistan bahwarisiko dislipidemia pada wanita meningkat seiring dengan bertambahnya usia dan juga dapat disebabkan karena peningkatan persen lemak tubuh dan nilaiIMTlebih dari normal. ${ }^{24,25}$

Sebanyak 26 subjek pada dua kelompok memiliki IMT dengan kategori overweight, obesitas Idan obesitas II.Pada keadaanoverweight dan obesitas sering terjadi gangguan metabolisme lipoprotein, sehingga menyebabkanterjadinya peningkatan kadar kolesterol LDL. ${ }^{26}$ Terdapat 8 subjek dengan kategori IMT normal namun memiliki kadar kolesterol LDL diatas normal. Orang dengan kategori IMT yang normal seharusnya memiliki kadar kolesterol LDL normal.
Peningkatan IMT 1\% dari kategori normal akan meningkatkan risiko penyakit kardiovaskuler 3,3\% pada wanita. Berkurangnya berat badan sebanyak 1 $\mathrm{kg}$ akan mengurangi kadar kolesterol LDL sebesar $0,68 \% .{ }^{27} \mathrm{Hal}$ ini tidak sesuai dengan penelitian di Jakarta bahwa tidak ada perbedaan kadar kolesterol LDL yang bermakna secara statistik antara kelompok IMT normal, overweight, dan obesitas I pada subjek usia 35-85 tahun. ${ }^{25}$

Berdasarkan hasil analisis statistik terdapat penurunan kadar kolesterol LDL kelompok perlakuan yang bermakna. Sehingga pemberian jahe merah 3,2 ml/kg BB per hari berpengaruh pada penurunan kadar kolesterol LDL. Semua subjek pada kelompok perlakuan mengalami penurunan kadar kolesterol LDL sesudah diberi jahe merah. Terdapat 5 subjek yang mengalami peningkatan dan 11 subjek yang mengalami penurunan kadar kolesterol LDL pada kelompok kontrol.Kepatuhan subjek pada kelompok perlakuan dan kontrol setiap hari dikontrol melalui formulir kepatuhan.Peneliti tidak dapat memastikan minuman diminum $100 \%$ karena tidak mungkin langsung dihabiskan saat diberikan pukul 08.00.Beberapa hal yang dapat mempengaruhi kadar kolesterol LDL di dalam penelitian ini yaitu faktor perancu berupa asupan makanan.

Asupan zat gizi mempengaruhi kadar kolesterol LDL dalam darah. Asupan kolesterol pada kedua kelompok sebanyak 18 orang berada dalam kategori lebih.American Heart Association (AHA) merekomendasikan untuk tidak mengonsumsi lebih dari $200 \mathrm{mg}$ kolesterol per hari. 
Asupan kolesterol yang berlebih hingga $500 \mathrm{mg}$ per hari dapat meningkatkan kadar kolesterol LDL. ${ }^{28}$ Asupan lemak pada kedua kelompok sebanyak 15 orang berada dalam kategori baik.Asupan yang kaya lemak jenuh dan kolesterol dianggap sebagai faktor penyebab meningkatnya prevalensi serangan jantung, infark miokard, hipertensi dan aterosklerosis. Untuk mencegahnya maka kadar lemak dalam darah harus pada batas aman. Cara menurunkan kadar lemak yang efektif adalah dengan mengonsumsi asupan makanan dari asam lemak tak jenuh ganda, omega-3, dan asam lemak omega- $6 .{ }^{5}$

Asupan serat pada kedua kelompok berada pada kategori kurang.Meningkatkan konsumsi makanan yang mengandung serat sebanyak 25-30 $\mathrm{g} /$ hari dapat menurunkan kadar kolesterolLDL. ${ }^{28}$ Asupan karbohidrat pada kelompok kontrol sebanyak 13 orang dan 18 orang pada kelompok perlakuan termasuk dalam kategori kurang.Diet karbohidrat yang sangat rendahefektif untuk menurunkan berat badan $7,6 \pm 0,7 \mathrm{~kg}$ serta kolesterol LDL 11,86 mg/dl selama 3 bulan pada wanita. ${ }^{29}$

Jahe merahpada penelitian ini diolah menjadi minumanyang terbuat dari jahe merah segar dengan penambahan air dan gula rendah kalori sebanyak 5 gram agar lebih diterima subjek. Jahe merah memiliki rasa kepedasan yang lebih jika dibandingkan dengan jahe jenis lainnya.Kepedasan jahe merah disebabkan oleh gingerol, yang merupakan bagian dari fenol. Konsentrasi gingerol pada jahe segar lebih banyak jika dibandingkan dengan jahe kering. ${ }^{11}$ Jahe merahdapat mengurangi kolesterol LDL dengan cara meningkatkan aktivitas enzim 7œ-hydroxylasedalam biosintesis asam empedu dan merangsang perubahan kolesterol menjadi asam empedu. ${ }^{12,13,30}$

Flavonoid dalam jahe juga dapat mengaktifkan sistem multi enzim, seperti sitokrom P-450 dan b5 yang mempengaruhi metabolisme lipid dan asam empedu. Enzim sitokrom P-450 dapat memediasi pembentukan asam empedu dari kolesterol melalui beberapa enzim sehingga jumlah asam empedu meningkat. Peningkatan tersebut dapat meningkatkan ekskresi asam empedu sebagai jalur utama eliminasi kolesterol. ${ }^{31}$ Asam empedu akan menghambat pencernaan makanan secara keseluruhan karena partikel lemak mencakup bagian dari makanan lain yang membuatnya tidak dapat dicerna oleh enzim pencernaan sehingga metabolisme lemak terganggu. ${ }^{10}$ Selain itu, flavonoid juga mengaktifasi reseptor LDL (apo B100, E). Peningkatan reseptor LDL mengindikasikan terjadinya penurunan kolesterol LDL. ${ }^{31}$

Jahe merah mengandung komponen bioaktif seperti [6]-gingerol, [8]-gingerol, [10]gingerol and [6]-shogaol secara berturut-turut sebesar $18.03 \mathrm{mg} / \mathrm{g}, 4.09 \mathrm{mg} / \mathrm{g}, 4.61 \mathrm{mg} / \mathrm{g}$, dan 1.36 $\mathrm{mg} / \mathrm{g} .{ }^{32,}{ }^{33}$ [6]-shogaol menunjukkan aktivitas scavenging 1,1 diphenyl-2 picyrlhydrazyl (DPPH) yang signifikan dibandingkan dengan gingerol.Xantin oksidase merupakan sumber radikal bebas oksigen. Pada fase reperfusi (reoksigenasi), xantin oksidase bereaksi dengan molekul oksigen, sehingga melepaskan radikal bebas superoksida. Gingerol dan shogaol menghambat produksi superoksida yang dihasilkan oleh xanthine/xanthine oxidase. Senyawa fenolik (gingerol dan shogaol) yang menghambat xantin oksidase atau yang menghambat produksi serta mengambil superoksida dikarenakan efek gabungan dari pengambilan superoksida dan penghambatan aktivitas dari xantin oksidase. ${ }^{32}$

Jahejuga meningkatkan kapasitas antioksidan plasma total dan menurunkan peroksidasi lipid.Peroksidasi lipid berkurang dengan berubahnya tingkatenzimatik superoksida dismutase, katalase, dan glutation peroksidase dalam darah. Jahe dapat mengurangi oksidasi selular dan mengambil anion superoksida dan radikal hidroksil.Aktivitas antioksidan dari jahe disebabkan oleh pengambilan anion superoksida dan radikal hidroksil oleh beberapa senyawa jahe seperti gingerol, shogaol dan beberapa turunan keton fenolik. ${ }^{13}$

Aktivitas antioksidan jahe merah segar sebesar $80,91 \%$ mengalami penurunan sesudah menjadi minuman jahe merah sebesar $62,19 \%$. Penurunan aktivitas antioksidan dapat terjadi karena terdapat penambahan air pada minuman jahe merah dengan rasio 1:10. Semakin tinggi rasio air yang digunakan maka akan menyebabkan kadar gingerol pada jahe menurun yang menyebabkan aktivitas antioksidannya menurun juga. ${ }^{19}$

\section{SIMPULAN}

Pemberian jahe merah $3,2 \mathrm{ml} / \mathrm{kg}$ BB per hari selama 21 hari memberikan pengaruhpenurunan yang signifikan terhadap kadar kolesterol LDL. Ada perbedaan rerata perubahan kadar kolesterol LDL antara kedua kelompok.

\section{SARAN}

1. Dilakukan uji laboratorium mengenai kandungan flavonoid pada minuman jahe merah.

2. Penderita dislipidemia dengan kadar kolesterol LDL lebih dari 100mg/dl hingga $159 \mathrm{mg} / \mathrm{dl}$ 
dapat meminum jahe merah sebagai salah satu sumber flavonoid sebagai minuman alternatif untuk menurunkan kadar kolesterol LDL dengan dosis $3,2 \mathrm{ml} / \mathrm{kg}$ BB per hari.

\section{DAFTAR PUSTAKA}

1. WHO. Cardiovascular diseases (CVDs) [2013 July 19]. Available from: who.int/mediacentre/factsheets/fs 317/en/index.htm 1.

2. Profil Kesehatan Provinsi Jawa Tengah2011.

3. Profil Kesehatan Kota Semarang Tahun 2012. 2013 Juni. Tersedia di: http://www.dinkeskotasemarang.go.id/?p=halaman_mod\&jenis=profi 1 .

4. Profil Kesehatan Kota Semarang Tahun 2013. 2014 Mei. Tersedia di: http://www.dinkeskotasemarang.go.id/?p=halaman mod\&jenis=profi 1 .

5. Sharma R, Moffatt RJ. Diet And Nutrition Therapy In Dyslipidemia. Dyslipidemia: Causes, Diagnosis and Treatment. India: Novapublishers Co.; 2011.

6. Phan BAP, Toth PP. Dyslipidemia in women: etiology and management. International Journal of Women's Health. 2014;6:185-94.

7. Plotto A. GINGER: Post-Production Management for Improved Market Access. Food and Agriculture Organization of the United Nations (FAO); 2002.

8. Malhotra S, Singh AP. Medicinal properties of Ginger (Zingiber officinale Rosc.). Natural Product Radiance. 2003;2(6).

9. Webb GP. Dietary Supplements \& Functional Foods. London: Blackwell Publishing; 2006.

10. Stoilova I, Krastanov A, Stoyanova A, Denev P, Gargova S. Antioxidant activity of a ginger extract (Zingiber officinale). Food Chemistry. 2007;102(3):764-70.

11. Ali BH, Blunden G, Tanira MO, Nemmar A. Some phytochemical, pharmacological and toxicological properties of ginger (Zingiber officinale Roscoe): a review of recent research. Food and chemical toxicology : an international journal published for the British Industrial Biological Research Association. 2008;46(2):409-20.

12. Srinivasan, Sambaiah. The Effect of Spices on Cholesterol 7 Alpha-Hydroxylase Activity and on Serum and Hepatic Cholesterol Levels in the Rat. Journal International de Vitaminologie et de Nutrition 1991;61(4):364-9.

13. Al-Azhary DB. Ginger Enhances Antioxidant Activity and Attenuates Atherogenesis in Diabetic Cholesterol-Fed Rats. Australian Journal of Basic and Applied Sciences. 2011;5(12):2150-8.

14. Mulyani SL, Orbayinah S. Pengaruh Serbuk Jahe Merah (Zingiber Officinale Rosc.) Terhadap Kadar Malondialdehyde (MDA) Plasma Pada Tikus Putih Terinduksi Karbon Tetraklorida (CCl4). Yogyakarta: Universitas Muhammadiyah Yogyakarta; 2010.
15. Prasad SS, Kumar S, Vajpeyee SK, Bhavsar VH. To Establish The Effect Of Ginger-Juice Zingiber Officinale (Zingiberaceae) On Important Parameters Of Lipid Profile. International Journal of Pharma Sciences and Research (IJPSR). 2012;2(4).

16. Paul P, Islam MK, Mustari A, Khan MZI. Hypolipidemic Effect Of Ginger Extract in Vanaspati Fed Rats. Bangl J Vet Med. 2012;10(1\&2):93-6.

17. Sultana S, Akter S, Khan MI. Anti-Hyperlipidemic Action Of Zingiber Officinale (Ginger) Juice In Alloxan Induced Diabetic Rats. Ibrahim Med Coll J. 2012;6(2):55-8.

18. Supriyanto, Cahyono B. Perbandingan Kandungan Minyak Atsiri Antara Jahe Segar Dan Jahe Kering.2012.

19. Mayani L, Yuwono SS, Ningtyas DW. The Effect of Size Reduction of Ginger and Water Ratio on Physical Chemical and Organoleptic of Ginger (Zingiber officinale) Extract. Jurnal Pangan dan Agroindustri. 2014;2(4):148-58.

20. Husein A, Karyomanggolo W, Dahlan AM, Aswhita B, Ismet NO. Desain Penelitian. 3 ed. Jakarta: Sagung Seto; 2008.

21. WHO. WHO Technical Report Series no 894. Genewa: WHO; 2000.

22. Gibson RS. Principles of Nutritional Assesment. 2nd ed. USA: Oxford University Press; 2005.

23. Supariyasa, Fajar I. Penilaian Status Gizi. Jakarta: Badan Penerbit Kedokteran EGC; 2001.

24. Humayun A, Shah A, Alam S, Hussein H. Relationship Of Body Mass Index And Dyslipidemia In Different Age Groups Of Male And Female Population Of Peshawar. J Ayub Med Coll Abbottabad. 2009;21(2):141-4.

25. Mawi M. Indeks Massa Tubuh Sebagai Determinan Penyakit Jantung Koroner pada Orang Dewasa Berusia diatas 35 Tahun. J Kedokter Trisakti. 2004;23(3):87-92.

26. Howard. BV, Ruotolo. G, Robbins. DC. Obesity and Dyslipidemia. Endocrinol Metab Clin N Am. 2003;32:855-67.

27. Anderson JW, Konz EC. Obesity and Disease Management: Effects of Weight Loss on Comorbid Conditions. OBESITY RESEARCH. 2001;9(4):326-34.

28. Krummel DA. Medical Nutrition Therapy for Cardiovascular Disease. In: Mahan LK, EscottStump S, editors. Krause's Food \& Nutrition Theraphy. 12 ed. Canada: Elsevier; 2008. p. 833-64.

29. Brehm. BJ, Seeley. RJ, Daniels. SR, D'alessio. DA. A Randomized Trial Comparing a Very Low Carbohydrate Diet and a Calorie-Restricted Low Fat Diet on Body Weight and Cardiovascular Risk Factors in Healthy Women. The Journal of Clinical Endocrinology \& Metabolism. 2003;88(4):161723.

30. Alizadeh-Navaei R, Roozbeh F, Saravi M, Pouramir M, Jalali F, Moghadamnia AA. 
Investigation of the effect of ginger on the lipid levels. Saudi Med J. 2008;29(9):1280-4.

31. Oliveira TT, Ricardo KFS, Almeida MR, Costa MR, Nagem TJ. Hypolipidemic Effect of Flavonoids and Cholestyramine in Rats. Latin American Journal of Pharmacy. 2007;26(3):407-10.

32. Dugasani S, Pichika MR, Nadarajah VD, Balijepalli MK, Tandra S, Korlakunta JN. Comparative antioxidant and anti-inflammatory effects of [6]gingerol, [8]-gingerol, [10]-gingerol and [6]shogaol. Journal of ethnopharmacology. 2010;127(2):515-20.

33. Fathona D. KANDUNGAN GINGEROL DAN SHOGAOL, INTENSITAS KEPEDASAN DAN PENERIMAAN PANELIS TERHADAP OLEORESIN JAHE GAJAH (Zingiber officinale var. Roscoe), JAHE EMPRIT (Zingiber officinale var. Amarum), DAN JAHE MERAH (Zingiber officinale var. Rubrum). Bogor: Institut Pertanian Bogor; 2011. 